\title{
Study of prevalence of maternal anaemia and its fetal outcome at rural tertiary care centre
}

\author{
Vandana Verma ${ }^{1}$, Soniya Vishwakarma ${ }^{1 *}$, Ramesh Chand ${ }^{2}$, Umesh Kumar Gupta ${ }^{3}$
}

\author{
${ }^{1}$ Department of Obstetrics and Gynecology, U.P.U.M.S, Saifai, Etawah, Uttar Pradesh, India \\ ${ }^{2}$ Department of Paediatrics, G.M.C, Haldwani, Uttarakhand, India \\ ${ }^{3}$ Department of Paediatric Surgery, U.P.U.M.S, Saifai, Etawah, Uttar Pradesh, India
}

Received: 25 July 2018

Accepted: 28 August 2018

\section{*Correspondence:}

Dr. Soniya Vishwakarma,

E-mail: dukg9999@gmail.com

Copyright: (c) the author(s), publisher and licensee Medip Academy. This is an open-access article distributed under the terms of the Creative Commons Attribution Non-Commercial License, which permits unrestricted non-commercial use, distribution, and reproduction in any medium, provided the original work is properly cited.

\begin{abstract}
Background: Anaemia is a major public health problem especially among low socioeconomic class of the population in developing countries. Prevalence of anaemia among pregnant women in developing countries is $51 \%$. Anaemia is defined by the WHO as haemoglobin levels of less than $11 \mathrm{gm} . \%$ in pregnancy. The present study was aimed to find out prevalence of anaemia in rural tertiary care centre to see the foetal outcome in anaemic women.

Methods: This is a retrospective observational study done in the Department of Obstetrics and Gynaecology, University of medical sciences Saifai, Etawah from June 2017 to November 2017. All the women admitted to labour room in third trimester and delivered here were included in the study excluding the patients with pre-eclampsia, eclampsia, gestational diabetes mellitus, heart disease, patients with other medical disorders and patients with twin pregnancy, antepartum haemorrhage and the patients who did not deliver here.

Results: Prevalence of anaemia was $87.3 \%$. severe anaemia was found in $3.5 \%$ women. The percentage of preterm births was more in anaemic women that is $16.9 \%$.

Conclusions: Anaemia in pregnancy is a major public health problem in India. The number of IUGR and LBW babies were more in anaemic women. Anaemia is related to serious consequences in mother and baby if not diagnosed and treated timely. It can be prevented by increasing the awareness regarding need of iron intake during pregnancy.
\end{abstract}

Keywords: Anaemia in pregnancy, Foetal outcome, IUGR, Preterm

\section{INTRODUCTION}

Anaemia is a major public health problem especially among low socioeconomic class of the population in developing countries. Prevalence of anaemia among pregnant women in developing countries is $51 \%$ whereas it is only $14 \%$ in the developed countries. ${ }^{1}$ Prevalence of anaemia in India is $65-75 \%$ in pregnant women. As per WHO, anaemia during pregnancy is defined as haemoglobin concentration of less than $11 \mathrm{gm} \%(7.45$ $\mathrm{mmol} / \mathrm{L}$ ) and haematocrit less than $33 \%$. India has the highest prevalence of anaemia. Women of child bearing age are at the maximum risk for development of anaemia. Anaemia is graded according to $\mathrm{Hb}$ level in three degrees mild (10-10.99 gm\%), moderate (7.0-9.9 gm\%) and severe degree $(<7.0 \mathrm{gm} \%)$ according to WHO. ${ }^{2} 87 \%$ of women have nutritional anaemia in the pregnancy due to iron deficiency. ${ }^{3}$ Iron deficiency during pregnancy is thought to be caused by a combination of factors such as 
previously decreased iron supply, the iron requirements of growing foetus and expansion of maternal plasma volume.

Maternal and foetal complications affect mainly in the women with unfavourable health conditions and lower socioeconomic status. Maternal mortality rates are higher in women with moderate and severe anaemia. Premature births are more common in women with moderate anaemia. Infection, maternal deaths due to ante partum and post-partum haemorrhage, pregnancy induced hypertension and sepsis occur in women with moderate anaemia. Severe Anaemia leads to cardiac decompensation when $\mathrm{Hb}$ falls below $5.0 \mathrm{~g} / \mathrm{dl} .{ }^{4}$ So anaemia is one of the major risk factors contributing to maternal death in developing countries. Anaemia during pregnancy is associated with IUGR, low birth weight, preterm delivery and increased perinatal mortality. ${ }^{4}$ The present study was aimed to find out prevalence of anaemia in rural tertiary care centre, and to see the foetal outcome in anaemic women.

\section{METHODS}

This is a retrospective observational study conducted in the Department of Obstetrics and Gynaecology at Uttar Pradesh University of Medical Sciences Saifai, Etawah from June 2017 to November 2017.

\section{Inclusion criteria}

- All the women admitted to labour room in third trimester and delivered at our institute.

\section{Exclusion criteria}

- Patients with preeclampsia, eclampsia, gestational diabetes mellitus.

- Patients with medical disorders like heart disease.

- Patients with twin pregnancy, antepartum haemorrhage.

- Patients who did not deliver at our institute. Diagnosed haemoglobinopathies, and bleeding disorders.
Data was collected from hospital records and was subjected to Statistical analysis.

\section{RESULTS}

The total no of deliveries in this period of 6 month was 4173. Out of which 1586 females were excluded on the basis of different exclusion criteria. Thus, the total included patients were 2587 . Out of these 2587 patients anaemia was found in 2259 patients i.e. $87.3 \%$. Only 328 females were non-anaemic (12.6\%). Mild anaemia was present in $80.12 \%$ females, moderate anaemia in $16.2 \%$ and severe anaemia was found in $3.5 \%$ women in $3^{\text {rd }}$ trimester of pregnancy.

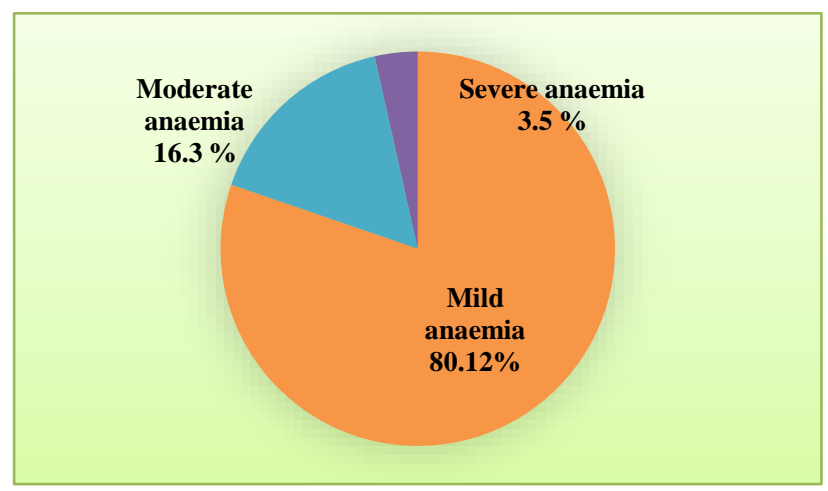

Figure 1: Distribution of patients according to grades of anaemia.

Most of the patients were in age group 20-35 years in both anaemic $(87.4 \%)$ and non-anaemic $(88.15 \%)$ women. Only $3.36 \%$ anaemic women were of $<20$ years of age whereas $3.3 \%$ non-anaemic women were $<20$ years age. 9.2\% women in anaemic group were more than 35 years of age and in non-anaemic group only 8.5 $\%$ women were > 35 years age. $47.18 \%$ women in anaemic group were primigravida and $56.81 \%$ nonanaemic women were primigravida (Table 1).

Table 1: Demographic profile.

\begin{tabular}{|c|c|c|c|c|c|}
\hline \multirow{2}{*}{\multicolumn{2}{|c|}{ Demographic profile }} & \multicolumn{2}{|c|}{ Non-anaemic $(n=328)$} & \multicolumn{2}{|c|}{ Anaemic (2259) } \\
\hline & & \multirow{2}{*}{$\begin{array}{l}\text { Number } \\
11\end{array}$} & \multirow{2}{*}{$\begin{array}{l}\text { Percentage out of total } \\
\text { non-anaemic mothers } \\
3.3\end{array}$} & \multirow{2}{*}{$\begin{array}{l}\text { Number } \\
31\end{array}$} & \multirow{2}{*}{$\begin{array}{l}\text { Percentage out of total } \\
\text { anaemic mothers } \\
3.4\end{array}$} \\
\hline & $<20$ years & & & & \\
\hline Age & 20-35 years & 289 & 88.10 & 803 & 87.4 \\
\hline & $>35$ years & 28 & 8.53 & 85 & 9.2 \\
\hline \multirow{2}{*}{ Parity } & Primigravida & 186 & 56.81 & 1066 & 47.18 \\
\hline & Multigravida & 142 & 43.29 & 1193 & 52.82 \\
\hline
\end{tabular}


The percentage of preterm births was more in anaemic women that is $16.9 \%$ where as in non-anaemic women this was $13.7 \%$. $46.2 \%$ babies in anaemic women had birth weight less than 2500 grams and $29.2 \%$ were with
IUGR (intra uterine growth restriction) whereas $40.2 \%$ non-anaemic women had babies with birth weight less than 2500 grams and the percentage of IUGR among them was $27.1 \%$ (Table 2).

Table 2: Fetal outcomes.

\begin{tabular}{|c|c|c|c|c|}
\hline \multirow[b]{2}{*}{ Parameters observed } & \multicolumn{2}{|c|}{ Non-anaemic } & \multicolumn{2}{|l|}{ Anaemic } \\
\hline & Number & $\begin{array}{l}\text { Percentage out of total non- } \\
\text { anaemic mothers }(n=328)\end{array}$ & Number & $\begin{array}{l}\text { Percentage out of total non-anaemic } \\
\text { mothers }(n=2259)\end{array}$ \\
\hline $\begin{array}{l}\text { No. of preterm births } \\
(n=429)\end{array}$ & 45 & 13.7 & 384 & 16.9 \\
\hline $\begin{array}{l}\text { No. of low birth weight } \\
\text { babies }(n=1179)\end{array}$ & 134 & 40.8 & 1045 & 46.2 \\
\hline $\begin{array}{l}\text { No. of IUGR babies } \\
(n=750)\end{array}$ & 89 & 27.1 & 661 & 29.2 \\
\hline
\end{tabular}

\section{DISCUSSION}

In this retrospective study the prevalence of anaemia was found to be $87.3 \%$ in third trimester of pregnancy. This is similar to the study done at SP Medical College Bikaner and a study done by J. Rajmaouli at Telangana in which they found the incidence of anaemia $91.3 \%$ and $96.8 \%$ respectively. ${ }^{4,5}$ In this study severe anaemia was found in $3.5 \%$ female which was lower than in the study done by J. Rajamouli $(5.2 \%){ }^{5}$ Similarly in a study conducted at Karnataka by R. Suryanarayan $3 \%$ patients were severely anaemic, $34 \%$ but in contrast to present study only $27 \%$ patients were having mild anaemia in their study. ${ }^{6}$ This much higher prevalence of severe anaemia may be because this is the tertiary care centre and all the referred cases come to our centre. In contrast to this study the prevalence was only $42.6 \%$ in study done by $\mathrm{R}$. Marahatta in Nepal. ${ }^{7}$ Most of the patients (in anaemic as well as non-anaemic) were in age group of 20-35 years in this study which is similar to study done by $\mathrm{R}$. Suryanarayana in which $66.1 \%$ anaemic women were in 21-30 years. ${ }^{8}$

Number of preterm births is more in anaemic women (16.9\%) compared to non-anaemic $(13.7 \%)$ in this study which is more than in study done by $\mathrm{R}$. Marahatta at Nepal. ${ }^{7}$ In this study low birth weight babies were $46.2 \%$ in anaemic women whereas it is $40.8 \%$ in non-anaemic women which is more than the study done by $\mathrm{S}$. Pagadpallithe in which incidence of low birth weight in anaemic women was $12 \% .^{9}$ In a study done by $\mathrm{K}$. Jagdeesh Kumar they found $6.5 \%$ increase in the incidence of low birth weight babies and $11.5 \%$ increase in preterm deliveries in mothers who were anaemic in their third trimester. ${ }^{10}$ In both the studies number of low birth weight babies were more in anaemic women. In the study done by V.B. Sangeeta they also found that low maternal haemoglobin levels are associated with increased risk of preterm delivery and LBW babies. ${ }^{11}$

\section{CONCLUSION}

The prevalence of maternal anaemia in this study was $87.3 \%$, which is a major public health problem. It has higher prevalence in third trimester of pregnancy in rural areas of India. It is related to serious consequences to mother and baby if not diagnosed and treated timely. The findings of this study show that there is strong association of maternal anaemia with increased risk of preterm, LBW babies, and IUGR. Anaemia can be prevented by increasing the better maternal and child health care and awareness regarding need of iron intake during pregnancy and consequences of anaemia in pregnancy. Prevention and early diagnosis of anaemia in pregnancy and its treatment can prevent serious complications to mother and baby.

\section{ACKNOWLEDGMENTS}

Authors are extremely thankful to all the participants for their valuable contribution to carry out this study.

\section{Funding: No funding sources}

Conflict of interest: None declared

Ethical approval: The study was approved by the Institutional Ethics Committee

\section{REFERENCES}

1. Mangla M, Singla D. Prevalence of anaemia among pregnant women in rural India: a longitudinal observational study. Int J Reprod, Contracep, Obstet Gynaecol. 2016;5(10):3500-5.

2. Bangal VB, Aher K, Bhosale K, Tuse H. Study of maternal and perinatal outcome in moderate to severe degree iron deficiency anaemia in rural community. Int $\mathrm{J}$ Biomed Advance Res. 2016;7(2):088-93. 
3. Mahamuda B, Tanira S, Feroza W, Perven HA, Shamim A. Effects of maternal anaemia on neonatal outcome- a study done in the specialized urban hospital set up in Bangladesh. Bang $\mathrm{J}$ Med Sci. 2011;10(3):177-80.

4. Bedi R, Acharya R, Gupta R, Pawar S, Sharma, Maternal factors of anaemia in 3rd trimester of Pregnancy and its association with faetal outcome. IMJH. 2015;1(7):9-16.

5. Rajamouli J, Ravinder A, Reddy S, Pambi S. Study on Prevalence of Anaemia among Pregnant Women attending Antenatal Clinic at Rural Health Training Centre (RHTC) and Chalmeda Anand Rao Institute of Medical Sciences Teaching Hospital, Karimnagar, Telangana, India. Int J Contemp Med Res. 2016;3(8):2454-7379.

6. Suryanarayana R, Santhuram AN, Chandrappa M, Shivajirao P, Rangappa SS. Prevalence of anemia among pregnant women in rural population of Kolar district. Int J Med Sci Pub Health. 2016;50(3):454-8.

7. Marahatta R. Study of anaemia in pregnancy and its outcome in Nepal Medical College Teaching Hospital, Kathmandu, Nepal. Nepal Med Coll J. 2007;9(4):270-4.
8. Suryanarayana R, Chandrappa M, Santhuram A N, Prathima S, Sheela SR. Prospective study on prevalence of anaemia of pregnant women and its outcome: A community-based study. J Family Med Prime Care. 2017;6(4):739-43.

9. Srinivas P, Srinivasan P. The relationship between maternal anaemia and birth weight in new born. J Dent Med Sci. 2015;14(12):9-11.

10. Kumar KJ, Asha N, Murthy DS, Sujatha MS, Manjunath VG. Maternal anemia in various trimesters and its effect on newborn weight and maturity: an observational study Int J Prev Med. 2013;4(2):193-9.

11. Sangeeta VB, Pushpalatha S. Severe maternal anaemia and neonatal outcome. Scholars J App Med Sci. 2014;2(1C):303-9.

Cite this article as: Verma V, Vishwakarma $S$, Chand R, Gupta UK. Study of prevalence of maternal anaemia and its fetal outcome at rural tertiary care centre. Int J Reprod Contracept Obstet Gynecol 2018;7:4077-80. 